\title{
Art Music by Caribbean Composers: St. Lucia
}

\section{Christine Gangelhoff \\ The College of The Bahamas ${ }^{1}$ \\ Cathleen LeGrand \\ Royal Thimphu College, Bhutan}

\section{INTRODUCTION}

St. Lucia sits in the eastern Caribbean and is one of the Windward Islands. Originally settled by the French in the 1600's, control was handed over to the British in the early 19th century ("St. Lucia," 2010). While English is the official language of the island, a French creole dialect is widely spoken ("St. Lucia," 1999). St. Lucia achieved independence from Great Britain in 1979 and remains part of the Commonwealth ("St. Lucia," 2010).

The island itself is mountainous and volcanic in origin ("St. Lucia," 1999). Colonizers founded plantations, predominantly sugar cane, and ran them using imported labour originally African slaves and, later, following the abolition of slavery, East Indian indentured workers (Renard, 2005).

Musical traditions of St. Lucia are in many ways similar to those of the other Caribbean islands colonized by the French. Lamagrit (La Marguerite) and Lawóz (La Rose), two societies founded in the 19th century, maintain and influence musical traditions. Both societies hold annual Flower Festivals which feature traditional and popular music (Renard, 2005). Music and dance derived from European dance traditions appear in indigenous forms on St. Lucia. Kwadril (the local creole spelling of quadrille), in particular was, until recently, a popular evening entertainment (Guilbault, 1998). The melodies for quadrilles and other Caribbean contra-dances are "predominantly European in character, although they may be enlivened by conventional improvised embellishments and syncopations, as when St. Lucian fiddlers alternate phrases (and often renditions of a given tune fragment) in binary and ternary meter" (Manuel, 2009, p. 24).

Music plays an important role in wakes and funerals. Musical choices at such events, from hymn singing to drumming, vary by religious affiliation (Guilbault, 1998).

Calypso and soca music arrived in St. Lucia from neighboring islands and local, indigenous versions soon arose and are commonly heard during carnival season (Renard, 2005).

Music education is a part of the public school curriculum in St. Lucia and private training is

\footnotetext{
${ }^{1}$ Christine Gangelhoff, Assistant Professor, School of Communication and Creative Arts, The College of The Bahamas, P.O. Box N-4912, Nassau, Bahamas; Cathleen LeGrand, Librarian, Royal Thimphu College, Ngabiphu, Thimphu, Bhutan.

Acknowledgments: The authors would like to thank Priscilla Lucien and Richard Payne for their contributions to and assistance with this chapter.

E-mail: cgangelhoff@cob.edu.bs
}

APA reference: Gangelhoff, C., \& LeGrand, C. (2013). Art music by Caribbean composers: St. Lucia. The International Journal of Bahamian Studies, 19(2), 55-57. https://doi.org/10.15362/ijbs.v19i2.192 
offered through the St. Lucia School of Music (Renard, 2005). The school was founded in 1987 and has campuses in Castries, Gros Islet and Vieux-Fort. The school "has several ensembles: an intermediate and advanced band, a string orchestra, a symphonic orchestra, a jazz concert band, a jazz combo, as well as a number of orchestras emerging from various community outreach programmes" ("St. Lucia School of Music," 2011). Through its innovative Manmay-la Di Wai (Children Make Music) project, the school seeks to "highlight the importance of indigenous music and musicians of the Caribbean as well as foster a greater appreciation for music from other parts of the world" ("St. Lucia School of Music," 2011). Current Executive Director of the St. Lucia School of Music, Richard Payne expresses concern at the "increasingly powerful influence of dance hall and hip hop music and

\section{REFERENCES}

Bluemango. (2008). Retrieved from http://www.myspace.com/bluemangomusic

Guilbault, J. (1998). St. Lucia. In D. E. Olsen \& D. E. Sheehy (Eds.), Garland encyclopedia of world music, volume 2: South America, Mexico, Central America, and the Caribbean (pp. 942-950). London, England: Routledge.

Manuel, P. (2009). Introduction: Contradance and quadrille culture in the Caribbean. In P. Manuel (Ed.), Creolizing contradance in the Caribbean (pp. 1-50). Philadelphia, PA: Temple University Press. other popular forms, particularly on the young, and how they are shaping new forms of musical expression" (R. Payne, personal communication, April 4, 2013).

Payne is an accomplished pianist and composer, as well as co-founder and leader of the regional jazz group, Bluemango. Payne and fellow Saint Lucian artist and composer Francis John, eager to "shape their concept of contemporary jazz music with a perspective born out of their own life experience ... decided to tap into the wellspring of the rich Creole heritage of their Caribbean homeland" ("Bluemango," 2008).

Musical training is also offered by the Royal St. Lucia Police Band. The Police Band also provides support to musicians, arrangers and composers throughout the community (Renard, 2005).

Renard, Y. (2005). St Lucia. In Continuum encyclopedia of popular music of the world: Locations. Retrieved from http://www.credoreference.com/entry/cont $\mathrm{pmwl} / \mathrm{st}$ _lucia

St Lucia. (1999). In Penguin encyclopedia of places. Retrieved from http://www.credoreference.com/entry/pene p/st_lucia

St Lucia. (2010). In The Hutchinson unabridged encyclopedia with atlas and weather guide. Retrieved from http://www.credoreference.com/entry/helic onhe/st_lucia

St. Lucia School of Music: About us. (2011). Retrieved from http://slumusicschool.com/about/ 


\section{COMPOSERS}

Charles Cadet (1924- )

Maurice Pierre

Leton Felix Thomas (1926- )

COMPOSITIONS, by composer

Cadet

Chanson Marianne

A dream of freedom (cantata, with Richard Beckford)

Just call on him

Mass for independence

On this day

Thomas

Sons and daughters of St. Lucia (1967, national anthem, lyrics by Rev. Charles Jesse)

\section{RECORDINGS}

Musical traditions of St. Lucia, West Indies [CD]. (1993). [Washington, D. C.]:

Smithsonian Folkways Recordings. Catalogue no. SFW40416.

[Includes kwadril music on tracks 114118]

\section{Thomas}

National anthems of the commonwealth [CD]. (2005). Hong Kong: Naxos. Catalogue No: 8.570126-27

Track 17. Sons and daughters of Saint Lucia (0:41)

National anthems of the world, Vol. 7. [CD]. (2006). Hong Kong: Marco Polo. Catalogue no: 8.225325

Track 15. Sons and daughters of Saint Lucia (0:41)

\section{SCORES}

\section{Thomas}

Sons and daughters of St. Lucia. www.nationalanthems.info/lc .jpg

\section{BOOKS AND ARTICLES}

Crowley, D. J. (1957). Song and dance in St. Lucia. Ethnomusicology, 1(9), 4-14. doi:10.2307/924597

Crowley, D. J. (1958). La Rose and La Marguerite societies in St. Lucia. The Journal of American Folklore, 71(282), 541552. doi: $10.2307 / 537460$

Guilbault, J. (1984). Musical events in the lives of the people of a Caribbean island, St. Lucia. Ph.D dissertation, The University of Michigan.

Guilbault, J. (1985). St. Lucian kwadril evening. Latin American Music Review, 6(10), 31-57. doi:10.2307/779964

Guilbault, J. (1987). Fitness and flexibility: Funeral wakes in St. Lucia, West Indies. Ethnomusicology, 31(2), 273-299. doi:10.2307/851893

Szwed, J. F., \& Marks, M. (1988). The AfroAmerican transformation of European set dances and dance suites. Dance Research Journal, 20(1), 29-36. doi:10.2307/1478814

\section{LIBRARIES}

Saint Lucia Folk Research Centre.

Mount Pleasant, P.O. Box 514, Castries,

Saint Lucia

Phone: (758) 452-2279 / (758) 453-1477

Fax: (758) 451-9365

Email: frc@candw.lc www.stluciafolk.org Business Hours: Monday-Friday: 8:30 am4:30 pm

St. Lucia School of Music

P.O. Box 972, Castries, St. Lucia

Castries: (758) 452-2473

Vieux-Fort: (758) 454-3083 | Fax: (758)

452-5989

Email: 1cmusicschool@candw.lc http://slumusicschool.com Business Hours: Monday-Thursday: 9:00 am-5:00 pm; Friday: 9:00 am-4:00 pm 